\title{
Tahfiz Students' Experiences in Memorizing the Qur'an: Unveiling Their Motivating Factors and Challenges
}

\author{
Nik Md Saiful Azizi Nik Abdullah \\ Kulliyyah of Education, \\ International Islamic University Malaysia, \\ Kuala Lumpur, Malaysia \\ nikazizi@iium.edu.my
}

\author{
Fathiyah Solehah Mohd Sabbri \\ Kulliyyah of Education, \\ International Islamic University Malaysia, \\ Kuala Lumpur, Malaysia \\ gadispejuang89@gmail.com
}

\author{
Rabi'atul Athirah Muhammad Isa \\ Universiti Kebangsaan Malaysia, \\ Selangor, Malaysia \\ irafansurie@yahoo.com
}

\begin{abstract}
This qualitative case study explores the factors behind Tahfiz secondary school students' motivation to undertake the challenging task of memorizing the Qur'an and the challenges they experienced. The participants were six (6) Tahfiz students (three boys and three girls), aged between 15 and 17, who were enrolled in the Tahfiz Al-Qur'an program in two public secondary schools in Gombak and Bangi. The participants were selected by their teachers through purposeful sampling and had been engaged in Qur'an memorization for at least 2 years at the onset of the study. In-depth, semi-structured one-on-one interviews were conducted to examine their views about the factors that motivated them to memorize the Qur'an and the difficulties they faced. The findings pointed to three distinct categories of motivating factors: the students themselves, teachers and parents. In particular, parental guidance and advice were the most influential elements in students' motivation to memorize the Qur'an. Among the challenges faced were time constraint, inability to remember verses, strict disciplinary rules and external noise that made the memorizing task difficult. In general, this study has shown the instrumental role of motivation in influencing Tahfiz students' memorization of the Qur'an.
\end{abstract}

Keywords: Qur'an learning motivation, Qur'an memorization, Tahfiz programmes, Qur'an learning challenges, external noise

\section{INTRODUCTION}

An increasing number of Tahfiz programs and classes have emerged in Malaysia recently, specifically in the state of Selangor. Thus, a growing number of Muslim parents desire to send their children to Tahfiz classes to become huffaz, i.e., Qur'an memorizers. Now, not only are more younger generation Muslims eager to learn and memorize the Qur'an, but the older generation are showing a greater interest to learn it as well. Statistics show that 815 Tahfiz schools are registered as public and private institutions in Malaysia. The approximate number of huffaz students at these centres was reported to be close to 47,474 (Nik Abdullah, 2019). 
In the state of Selangor, there are around 382 Tahfiz institutions spread throughout all districts (Nik Abdullah, 2019). Table 1 below shows the distribution of Tahfiz institutions in all districts of Selangor.

\section{Table 1}

Distribution of Tahfiz Institutions in Selangor (2019)

\begin{tabular}{|c|c|}
\hline District & No of Tahfiz Institutions \\
\hline Sepang & 24 \\
\hline Hulu Langat & 72 \\
\hline Kuala Langat & 31 \\
\hline Hulu Selangor & 25 \\
\hline Kuala Selangor & 44 \\
\hline Klang & 41 \\
\hline Petaling & 80 \\
\hline Sabak Bernam & 17 \\
\hline Gombak & 44 \\
\hline Maahad Integrasi Tahfiz Sains (State) & 04 \\
\hline Total & 382 \\
\hline
\end{tabular}

The opening of many Tahfiz institutions, programmes and classes makes it much easier for people in the Muslim community to learn to memorise the Qur'an, because it is not strictly for children. The first Tahfiz institution, Maahad Tahfiz al-Qur'an wal Qiraat known as Darul Qur'an Jakim could be considered as the starting point which inspired many other educational institutions to further develop their own modules and techniques on Qur'anic memorization (Nik Saiful Azizi, 2014). The Government also agreed to implement the Tahfiz Model of Ulul Albab (TMUA) in all public secondary schools using the Integrated Tahfiz Curriculum. The curriculum emphasizes the Qur'anic approach, the encyclopedic approach, and the ijtihadik (high-level thinking) approach, that enable students to memorize 30 chapters of the Qur'an, to become good professionals with strong religious foundations based on the Qur'an and Sunnah, competent, credible and concerned, while at the same time maximizing higher-level thinking and building relationships with Allah, fellow humans and the universe (Ministry of Education, 2016).

However, no matter how good the Tahfiz programmes are, they are not complete without understanding the motivation that drives the students to undertake the challenging task of memorizing the Qur'an. Being motivated would boost the level of repetition to continue learning and memorizing the Holy Book. The process of learning to memorize the Qur'an is not merely about techniques, but also how much students value and have a deep interest in the subject during the process of learning. When students fail to see the significance of learning, they tend to lose interest and motivation in the class, no matter what subject they are learning, as motivation plays a crucial role in engaging them to learn (Wirth \& Perkins, 2007). Mc Carty and Siccon (2001), as cited in Saudullah Ali (2003), stressed that the lesson itself should be meaningful, and the information presented by the teachers should be important and relevant to students' interest. This is essential as students' motivation is greatly dependent on the curriculum, syllabus and textbooks on the subject, as well as on parents' role in encouraging 
their children. If students perceive the subject as being relevant and important to them, they will then find the learning to be meaningful. Students should be able to relate what they are reading to the real world in their Tahfiz lessons. Students need to feel the urge and the importance of memorizing the Qur'an so that they will value what they memorize and be able to communicate it to others.

Meanwhile, The American Educators' Encyclopedia in defining motivation stated that it is a psychological concept in human behavior that describe a predisposition towards a particular behavior to satisfy individual need. Brophy (1998) defined motivation as a theoretical construct used to explain the initiation, direction, intensity, and persistence of behavior, especially goal directed behavior. Motivation refers to students' subjective experiences, especially their willingness to engage in lessons and learning activities and their reasons for doing so. Highly motivated people expand their effort to achieve their desired goals, unlike unmotivated people who desist when difficulties or problems arise. This statement clearly shows that intrinsic motivation is something that already exists within the individual self.

In memorizing the Qur'an, one needs two elements, understanding and motivation, so that memorization can become a meaningful effort. In his analysis of comprehension and memorization, Entwistle (2003) has shown that learning through repetition is the basis of knowledge. However, students tend to get bored when they have been memorising for too long, so they need some motivation to keep going. Furthermore, according to Benta and Cremene (2004), as cited in Nor Musliza Mustafa and Mokmin Basri (2014), when students feel motivated they are able to understand better, which in turn enhances meaningful retention and recall of the learning. This is extremely important in memorizing the Qur'an as students can memorize faster and understand the verses better.

\section{Study Settings}

The research involved six students enrolled in the Tahfiz program in Sekolah Menengah Islam Al-Amin Gombak (SMIAAG) and Sekolah Menengah Islam Al-Amin Bangi (SMIAAB). These two schools, in particular, have started the Tahfiz Al-Qur'an program in order to fulfill the needs of people in the community who aspire to become huffaz. This program was oversighted by the Parent-Teacher Association (PTA) and Al-Qur'an Department in both schools. The programme was included in the school curriculum every morning during the AlQur'an study period, followed by 3-day classes a week, Mondays, Wednesdays and Thursdays from 3:45 p.m. to 5:45 p.m. Intensive courses were also provided during school breaks for those who would like to attend. The aim of this programme was to produce huffaz by the age of 16 . Bahasa Melayu is used as the medium of instruction, and its own curriculum modules for the programme have been implemented. Thus, the Tahfiz curriculum in these schools serve as a platform for students to learn how to read and memorize the Qur'an in accordance to the Islamic standards of tajwid. Lastly, this program enables students to develop Qur'anic recitation skills and correct common mistakes in their 5 daily prayers (Al-Amin Tahfiz Center, 2012). 


\section{Studies on Qur'anic Recitation and Memorization}

Boyle (2006), after conducting ten months of fieldwork on the practices and traditions of Qur'anic memorization in Morocco, concluded that Qur'anic memorization is a process of embodying the divine, the words of God, and as such is a far more learner-oriented and meaningful process than is typically described. The mission of the contemporary Qur'anic education, with Qur'anic memorization at its core, is concerned with developing spirituality and morality as well as providing an alternative to public education, when the availability and the quality of public education is limited (p. 478).

Tuckman and Monetti (2010) stated that several factors affect memorization, including how much the information gave meaning through practices and organization of information, as well as how much the information was transferred to an individual. Meanwhile, Mumford (1986), as cited by Muhamad Hafiz Khamis (2011), said that students should use at least one of the learning styles in memorizing the verses of the Qur'an. In addition to this, students should also memorize the verses line by line from every page in the Qur'an. This is to ensure that the students do not lose motivation while memorizing as well as helping them to recognize each word without leaving anything out. The result of the above finding had been proven by Abdulsalam (2008) in his study on Qur'anic memorization. He stated that the Qur'an can be memorized line by line to enable students to comprehend and memorize the verses better and faster. A study carried out by Norkhairolizah (2005) found that parents played a great role in developing children's mind-set and their academic goals, while at the same time establishing routines and monitoring their memorization of the Qur'an.

In addition to that, parents also took part in providing and giving a good environment for Qur'anic memorization and provided support to their children. This is in accordance to AlGhazali's idea that since the first teacher of a child are the parents. It is the parents' responsibility to teach their children proper manners and character (Adam, 2016).

While another study done by Ariffin (2013) on the effective techniques of memorizing the Qur'an at Madrasah Tahfiz al-Qur'an in Terengganu, found that students could memorize the whole Qur'an within 15 hours without looking at the mushaf through four methods: sabak memorization, para sabak, ammokhtar, and halaqah dauri. Other studies on the selection of a good module for Qur'anic memorization in accordance to one's capability showed that students should spend more time repeating the memorization of the same verses and only a little time on a new verse. While the age factor turned out not to be an obstacle for someone to memorize the Qur'an, only interest, ability, and actions are considered to be obstacles for them (Ariffin et al., 2013).

In addition, the researcher found that the efficacy was mainly due to the influence from parents, teachers' guidance, students' interest and their attitudes in the recitation of the Qur'an (Shahrudin et al., 2015). A further study by Azmil Hashim et al. (2014) on the relationship between tahfiz etiquettes and tahfiz achievement has shown that attention needs to be paid to the teaching and learning curricula of tahfiz in order to improve student achievement in the memorization of the Qur'an. A study on learning methods and problems of Malay and African 
reciters of the Qur'an found that when they are able to understand the Arabic language, the level of fluency, understanding of Qur'anic words and even remembering the rules of Qur'anic recitation (tajwid) can be increased (Yusof et al., 2012).

In addition to the study on the use of mim-mem (mimicry and memorization) done in the Tahfiz al-Qur'an class in Kampar, Indonesia, found that students were more motivated to learn al-Qur'an as they did not have to focus only on memorization but they could also learn from listening to their teachers' pronunciation (Zahera, 2012). Another research done by Waenalai (2009) on learning the memorization of al-Qur'an in Ma'had Nahdhotul 'Ulum Yala, South Thailand, found that one of the barriers which hindered students' interest in memorization of the Qur'an was the lack of concentration.

In summary, the path of memorizing the Qur'an might not always be bright and easy. But Allah has promised His help in this matter in the Qur'an, "as for those who struggle for Our sake, we will guide them in Our ways. For God is with those who do good" (Al-Ankabut, 29:69). While in another verse, Surah Ali Imran: 159 and 160, Allah motivates people to put their trust in Him as He is the one that can help you during difficulties. "Put your trust in Allah. Allah loves those who trust (in Him). If Allah helps you, none can overcome you. If He forsakes you, who is there, after that, that can help you?" These verses clearly show that students need to be able to trust Allah and relying on His help when reciting and memorizing the Qur'an as Allah will help clear their path from any obstacles and difficulties.

\section{Statement of the Problem}

Generally, memorization of the Qur'an in Malaysia, particularly Sekolah Menengah Islam AlAmin Gombak (SMIAAG), is still focusing more on memorization of the text without realizing that understanding of the contents of the Qur' an is also important. Sternberg (2003), as cited in Muhammad Ikhwanuddin (2013), mentioned how educational institutions only promote rote learning through recitation and repetition whilst ignoring that evaluation and interpretation is also crucial. He added, by citing Westwood (2004), that rote learning encourages students to commit to memory information which is not understood and have no functional value, where information stored is not easily retrieved and is also easily forgotten. Hence, when students memorize the Qur'an without understanding the meaning of the verse, they could lose their memorization quickly.

Studies related to motivation in learning had been developed and discussed for many years. Aragon (2002) in his study on motivation asserts that students preferred teachers who provide feedback, who actively participate in students' learning as well as the materials used in supporting learning. Meanwhile, studies on motivation in recitation and memorization of the Qur'an had just recently been expanded by researchers.

Additionally, based on the review of studies on Qur'anic memorization with relation to motivation, there are only a few studies related to parental role in promoting Qur'anic memorization. A study done by Norkhairolizah (2005) found that parents played a greater role 
in developing children's mind setting and academic goal, while at the same time establishing routines and monitoring their memorization of the Qur'an. In addition to that, parents also took part in providing and giving a good environment for Qur'anic memorization and support to their children. Thus, this present study fills the gap on students' motivation in memorization of the Qur'an while at the same time stressing on the barriers faced by students and how they overcome the barriers, particularly in SMIAAG and SMIAAB. As such, due to students' poor motivation, this study aims to explore the factors behind motivation in the memorization of the Qur'an.

\section{Objectives of the Study}

As students need motivation to learn, it is important to research the variables behind their eagerness to learn. This study set out to explore the factors behind motivation in the memorization of the Qur'an, to investigate the difficulties that block the motivation of the students while memorizing the Qur'an and to explain the strategy adopted by students to overcome the obstacles in memorizing the Qur'an.

The following research questions are formulated to further expand on the motivation and challenges of students in Tahfiz classes in order to achieve the goals of the research, namely:

1. What are the factors that explain Tahfiz students' motivation to memorize the Qur'an?

2. What are the challenges that hamper their motivation to memorize the Qur'an?

3. How do the students overcome the challenges of memorizing the Qur'an?

\section{Conceptual Framework of the Study}

Motivation-related studies have long been discussed by scholars. However, motivational studies in Islam have only recently increased in number. Since the focus of the current study is on motivation in Qur'anic memorization, which is part of Islamic studies, it is important to point out the Islamic motivational perspective. Seifert (1999) mentioned that motivation refers to the impact of reinforcement on behavior. A reinforcement that works effectively is considered to be motivating. If receiving gold stars for academic performance encourages the student to work harder, then gold stars are elements of motivation; if praise is what works, then praise is motivating. Furthermore, motivation in Islam can be divided into two parts: the intrinsic and the extrinsic motivation. Intrinsic motivation stems from one's own desire to meet or overcome challenges. So, they do not need any incentive to encourage them to do any kind of work. Satisfaction from the work itself is a reward for them.

According to Alizi and Mohammad Zaki, (2005), extrinsic motivation refers to motivation to perform a behavior in order to get rewards and avoid punishment. They added that intrinsic motivation may decrease due to extrinsic rewards. They queried further: Should Muslims perform ibadah as a submission to Allah or because they are afraid of the consequences that comes by neglecting it. They then point out that those with a high level of iman would be more likely to perform ibadah for the sake of Allah. Therefore, extrinsic 
motivation can help teachers in motivating students. Gold stars, tokens, candy, stickers, honor rolls, special treats like field trips, praise, test grade and class rank are among the familiar extrinsic motivators teachers routinely use by providing students with something they desire.

Ola Abdel-Kawi and James Kole (1991) have argued that extrinsic motivation helps to encourage Muslims to do better. In their observation of the Islamic model of the motivation process, it follows the following sequence: it begins with an explanation of the rewards given, through past experience of satisfaction, followed by a good behaviour. Chang (2005), as cited in Garcia \& Pintrich (1996), then defined intrinsic motivation as participation in an activity due to curiosity and one's desire to engage and contribute to something. When students engage in this kind of motivation, they tend to develop their own goal that they want to achieve regardless of the challenges ahead. In addition to that, Dev (1997), as cited in Chang (2005), also defined extrinsic motivation as an outside motive in response to the goal provided in front of them. $\mathrm{He}$ gave an example of a student who studied hard to get a good grade so that he/she could get a new car. Thus, learning through extrinsic motivation can hardly lead them to study for the purpose of knowledge, but rather to be manipulated by other things. Salasiah, et al. (2011) provided an overview of the factors behind their motivation in their research on student motivation in Islamic education. The figure below shows their model of learning motivation factors.

\section{Figure 1}

Learning Motivation Factors adapted from Salasiah, et al. (2011)

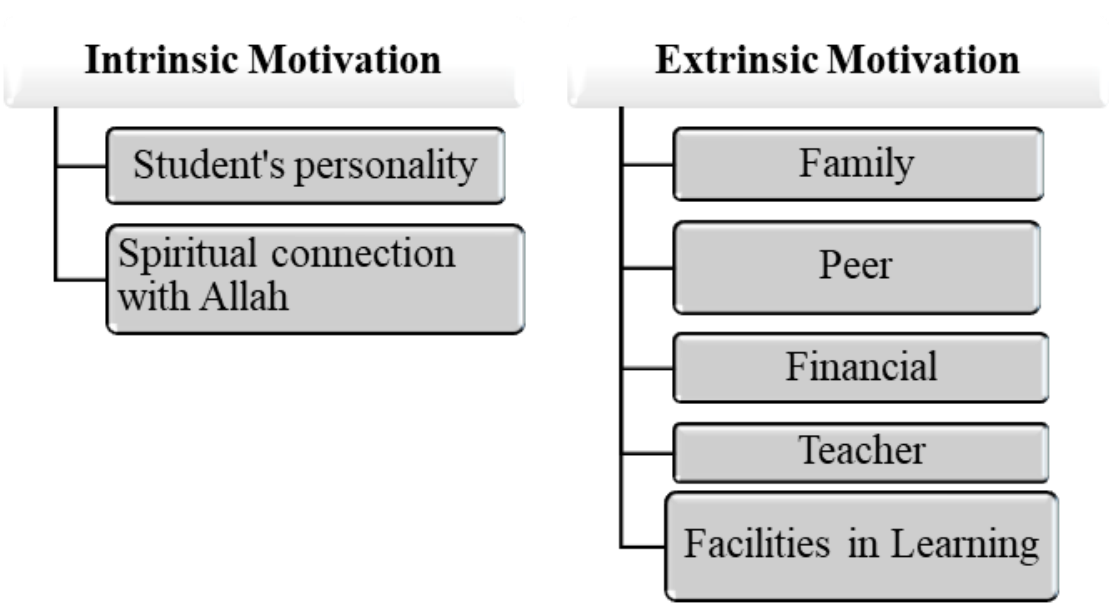

\section{METHODOLOGY}

This study encompassed a qualitative case study design to explore the factors behind students' motivation in Qur'anic memorization in the Tahfiz class of the normal high school setting. A case study permits the researcher to explore a phenomenon within its context through a variety of angles that help them to understand the phenomenon (Baxter \& Jack, 2008).

In-depth, semi structured interviews through one-on-one interaction were used to investigate participants' views about their learning motivation. This allowed them to share their experiences on learning and what motivated them to continue memorizing the Qur'an. The 
researcher used an open-ended interview structure which included specific questions, followed by probing questions to investigate the phenomenon in-depth. The participants were asked a standard set of questions. Nachmias and Ismail (1996) suggested a suitable approach in conducting the interview:

\begin{abstract}
"The personal interview can be regarded as a face-to-face interpersonal role situation in which an interviewer asks respondents questions designed to obtain answers pertinent to the researcher's hypotheses. The questions, their wording, and their sequence define the extent to which the interview is structured" (p.5).
\end{abstract}

\title{
Participants
}

The total population of 245 students (SMIAAG) and 150 students (SMIAAB), respectively, that enrolled in the Tahfiz class was between 13 and 17 years of age. They were selected based on the results of the interview and the Qur'anic reciting test performed before being admitted to the class according to their ability and level of memorization of the Qur'an.

The researcher chose Form 4 students because they were mature enough to understand the situation, while at the same time they could be easily reached through at least one social media if there was any urgent need for attention in the study.

The number of participants selected in this study was 6 Tahfiz students ( 3 females and 3 male) out of 395 Tahfiz students in the school, and their age ranged between 15-17 years, and currently enrolled in the Tahfiz Al-Qur'an program in Sekolah Menengah Islam Al-Amin Gombak and Al-Amin Bangi, respectively. Three participants were selected from SMIAAG (1 male and 2 females), while the other three were selected from SMIAAB (2 males and 1 female). Each participant had been exposed to Qur'anic memorization for at least 2 years.

The participants were selected by their teachers through purposive sampling. This was seen important as their teachers knew their students better. According to Seidman (2006), as cited by Patnaik (2014), purposive sampling helps the researchers to focus on participants with directly related experiences and able to share their stories and experiences better.

\section{Table 2}

Characteristics of the Participants

\begin{tabular}{lll}
\hline Characteristics & Gender & $\mathrm{n}$ \\
\hline SMIAAG & Male & 1 \\
& Female & 2 \\
SMIAAB & Male & 2 \\
& Female & 1
\end{tabular}

Note. $\mathrm{n}$ indicates the number of students involved 


\section{Trustworthiness of the Instrument}

Bleich, E., \& Pekkanen, R. (2013) believed that the reliability of data depends on three fundamentals, namely, the representativeness of the sample, the type and quality of information obtained, as well as the accuracy of reporting. To ensure the confirmability and trustworthiness of the research, the researcher first gave out the interview questions to an expert in motivation and Tahfiz. The result then became a baseline for the researcher to conduct a pilot study using the instrument. In the pilot study, one participant from Maahad Tahfiz Suleimaniyyah, Bangi, was selected to participate. The researcher found that the participant was able to understand the questions given and responded to it attentively. Thus, the answers gained from the participant determined the confirmability of the research

\section{FINDINGS}

The results and findings of this study are as shown below:

\section{Participant Demographics}

Based on the interview, the researcher found that three participants were from religious educational family backgrounds, and another three were from non-religious educational backgrounds. However, only two participants had been exposed to Qur'anic memorization for more than 5 years. The rest of the participants were only exposed to Qur'anic memorization during their secondary years. Table 4.2 below summarized the students' demographic background.

Table 3

Participant Demographics

\begin{tabular}{cccc}
\hline $\begin{array}{c}\text { Participant } \\
\text { ID }\end{array}$ & $\begin{array}{c}\text { Family } \\
\text { Background }\end{array}$ & No/Siblings & $\begin{array}{c}\text { Years of Exposure to } \\
\text { Qur'an Memorization }\end{array}$ \\
\hline P1 & R & $1 / 5$ & 7 \\
P2 & R & - & 2 \\
P3 & R & $7 / 8$ & 7 \\
P4 & NR & $3 / 3$ & 3 \\
P5 & NR & $1 / 4$ & 4 \\
P6 & NR & $5 / 10$ & 2 \\
\hline
\end{tabular}

Note. R indicates religious, NR indicates non-religious,'-' indicates not stated

Based on the previous table, all participants agreed that family influence was the main reason for their motivation in memorization. Meanwhile, only three participants agreed that they themselves were motivated to memorize the Qur'an, followed by only one participant who thought that teachers were the ones who motivated him to memorize. 


\section{Self-Influence}

Undeniably influential factor in the memorization of the Qur'an was ourselves. Some of the reasons that could be identified were the feeling of importance to memorize, to improve prayer performance and control emotion, to set an example, as well as to have a strong memory.

"I think that it is important to live and die with Al-Qur'an. So, I can say that this is what motivated me to further memorizing of the Qur'an." (Participant 1)

“... I guess I can say that I memorize the Qur'an to be able to perform prayer even better with choices of verses to pick..... Well I think when I memorize the Qur'an, I am able to control my emotion" (Participant 4)

"I think me myself are motivated to learn the Qur'an more..since I am the oldest in my siblings, I would like to be an example to my siblings...” (Participant 5)

"emm..saya rasa sebab saya dengar orang yang banyak hafal ni ingatan dia kuat..senang belajar...mungkin sebab tu kot saya lagi tertariknak menghafal..kalau dulu saya baca, x paham pun maksud ayat tu..tapi sekarang boleh la sikit-sikit" ["emm...I think it is because I heard people who memorize a lot have a strong memory..easy to learn..maybe that's why I am more interested to memorize...before, I can't understand what I read, but now I can understand a bit”.] (Participant 6)

\section{Family Influence}

Participant 1," Every morning, before going to school, my father will check our memorization first.."

Participant 2: "my family...especially my older sister..she really inspires me to memorize."

Participant 3:"..tapi bukan mak saya je..abah..adik-beradik banyak jugak bagi nasihat” ["..but not only my mother, my father and other siblings also gave a lot of advice.”]

Throughout the interview, the researcher found that several factors including strict teaching and management of time as well as the aspiration from someone close were the leading cause of the influence. Participant 1 said, ".. if we failed to memorize clearly, he will add another 3-4 ayah and for us to memorize when we are back at home..."

This clearly shows the strict teaching in memorizing as the participant needed to memorize the Qur'an properly so that one does not have to do the punishment though it is a good punishment. She added by saying that her mother was the one who managed her time to memorize while at the same time monitors her memorization, 
"well..aside from my father, my mother also monitor our memorization sometime"

"..she is more focus on how we manage our time in memorizing and other things.."

Apart from that, the other participants identified aspiration from someone close did motivate them to memorize the Qur'an. Participant 2 says:

“...especially my older sister..she really inspires me to memorize."

While participant 3 mentioned that as all of her siblings memorized the Qur'an, she also became motivated to memorize. Her mother also gave quite impressive advice which encouraged her more.

"alhamdulillah, dalam keluarga saya semua hafal Qur'an..Cuma saya dengan yang bongsu je masih belum habis..rasa dalam 10 juz lagi”. ["praise be to Allah, all my family members memorize the Qur'an...only me and the youngest one haven't finished memorizing.. the youngest..I think its around 10 chapters more.."]

"nasihat dari mak saya, memang dia nak sangat anak-anak dia semua hafal Qur'an sebab itulah harta berharga yang dia boleh bagi pada kitaorang adik-beradik...dan dia selalu pesan hafal Qur'an memang senang, tapi nak kekalkan sampai akhir hayat tu yang payah..kalau kitaorang nak sambung belajar ke, g mana-mana ke, benda yang dia pesan jaga Qur'an.." [“advice from my mother, she really wants all her children to memorize the Qur'an as that's the only valuable possession she can give us.. and that memorizing is easy, but to maintain our memorization until the end of our lives is what makes it hard...even if we want to further study or going somewhere, things she always remind us for is take care of our Qur'an."]

Meanwhile both participants 4 and 6 agreed that their parents were actually the ones who admitted them to the program while participant 5 when asked about this said that he himself asked his parents if he could enroll into the Tahfiz program as he wanted to encourage his siblings to follow him in memorizing the Qur'an too.

"maybe I could say my parents and relatives... according to what my mom had said before, my KAFA teacher always told her send me to any memorization class if possible as my recitation is very good." (Participant 4)

" ayah dan mak saya yang masukkan saya kat sini.." ["both my father and mother admitted me here..”] (Participant 6)

"I want my siblings to follow my path..." (Participant 5)

\section{Teacher Influence}

This is different, the answer from respondent 3 where she said that teachers gave a lot of support in memorizing: "kalau kat sekolah..cikgu pun banyak ajar dan bantu saya menghafal.." ["at school, teachers taught a lot and helped me in memorizing.. ”] (Participant 6). 
Based on the above results, the participants agreed that the influence of the self, family and teacher were factors to enhance their motivation for memorization.

\section{Challenges in Memorization of the Qur'an}

Challenges are something which cannot be avoided while memorizing the Qur'an. Allah has promised His help in this matter in the Qur'an, "As for those who struggle for Our sake, we will guide them in Our ways. For God is with those who do good" (Al-Ankabut, 69). In the Table 5 below, the challenges in memorization of the Qur'an were identified and listed. From the table below, the researcher found that time constraint, lack of motivation, inability to recall, emotional challenge, as well as external noise, were the challenges which impeded participants' motivation in memorizing.

Table 5

Five Challenges in Qur'anic memorization

\begin{tabular}{cccccc}
\hline Participant & LM & TC & UR & EC & EN \\
\hline P1 & $\sqrt{ }$ & $\sqrt{ }$ & & & \\
P2 & & $\sqrt{ }$ & $\sqrt{ }$ & $\sqrt{ }$ & \\
P3 & & $\sqrt{ }$ & & & \\
P4 & & & $\sqrt{ }$ & $\sqrt{ }$ & \\
P5 & & $\sqrt{ }$ & & & $\sqrt{ }$ \\
P6 & & $\sqrt{ }$
\end{tabular}

Note. LM indicates lack of motivation, TC indicates time constraint, UR indicates unable to recall, EC indicates emotional challenges,

EN indicates external noise

From the table above, the researcher found that most of the participants agreed that time constraints had become a challenge for them to overcome. While the other challenges, such as not being able to recall and emotional challenges, were the second challenges they faced. Only one student felt that it was due to the lack of motivation or external noise that made it difficult for her to memorize the Qur'an. However, three participants were unresponsive as they did not want to share more information on what they faced while memorizing.

\section{Lack of Motivation}

One of the participants when asked about her challenges in memorizing stated that she was more occupied with technology and spent most of the time looking at her gadget.

"errr.talking about motivation..I think I am lacking at motivation to memorize. Since technology is everywhere nowadays, I spend mostly on gadget and more motivated to occupy myself with facebook..,twitter.." (Participant 1) 


\section{Time Constraint}

Four out of six participants said that time constraints were always a problem during the memorization of the Qur'an.

"it's the time constraint. I have a lot of other work to do especially now I am in form 4..the workload is getting bigger.." (Participant 1)

"ermmm..mungkin jugak masa kot..sebab bila dah naik form 4 ni, kerja pun makin banyak..tambah pulak nak kena hafal Qur'an jugak dalam masa yang sama” ["ermmm..maybe its also due to the time..because now that she is in form 4, the workload is getting bigger, plus she need to memorize the Qur'an at the same time.. '] (Participant 3)

"I think...it's about management of time...I still could not get enough time to recall every single verses that I had memorize carefully..." (Participant 4).

Another participant said that:

"saya baru masuk je jadi memang terkejar-kejar jugak la silibus tu..kalau kawankawan yang sebaya dah nak habis 25 juz, saya baru dalam 15 juz kot.." ["I've just been enrolled in this school, so I've got a lot of syllabus to cover... my same age friends are already in chapter 25, but I'm just around chapter 15. '] (Participant 6)

\section{Unable to Recall}

Sometimes, the challenges might not come from external but internal factors. To be able to recall things that we had memorized might be quite a challenging task when our brain cannot retrieve the information when needed. Participant 2 stated that:

“..I did have problem while memorizing..especially when I want to continue reading the verse.."

In addition to that, he also identified:

"I also faced problem in recalling back the beginning of ayat or even remember their page.."

This is similar to the response of participant 5 who stated that,

"sometimes I can't even recall the verses back when I am under stress.."

From this point on, the researcher found that both participants 2 and 5 had difficulty recalling their memorization. Sometimes they were stuck reading the verses and other problems related to memory retrieval. 


\section{Emotional Challenge}

Apart from the above, emotions also became a challenge to participant 3 as she felt uneasy to cope with strict discipline in memorizing the Qur'an while at the same time feeling lazy to do anything sometimes makes it harder for her to focus on memorizing.

"Cuma mencabar sikit dari segi emosi." [“Just, it's a little challenging emotionally...”]

"ye la kalau nak menghafal ni kena ada disiplin yang kuat..orang lain bercuti..kita kena menghafal..tak rasa macam bercuti sangat pun sebab mesti ada kerja rumah cikgu bagi suruh hafal..jadi tak 'best' sangat la.." ["if we want to memorize, we need strong discipline...when other people go on vacation, we need to memorize...so it doesn't really feel like a vacation...it has to be homework to do so...not it's really fun.”]

"tu tak campur malas lagi..kadang-kadang terasa tak ada mood nak buat apaapa.." ["feeling lazy also quite an obstacle..sometimes I do not feel like doing anything..”]

Meanwhile, participant 5, when asked about his challenges, answered that he felt the pressure to set an example to his siblings.

"I am the oldest in my siblings, I would like to be an example to my siblings..."

\section{External Noise}

The interview with participant 6 somehow was different from others. Participant 6 mentioned the noisy environment at school which was kind of distracting him in doing the memorization.

"I am the oldest in my siblings, I would like to be an example to my siblings..."

"saya rasa keadaan persekitaran kat sekolah macam x berapa menarik minat saya untuk hafal Qur'an...sebab kadang-kadang bising...kelas ni buat lepas waktu sekolah..masa budak-budak sekolah rendah dah boleh balik...akak tengok kan yang sekolah ni sebelah je dengan sekolah rendah..." ["I think the school environment somewhat did not encourage me to memorize the Qur'an..because sometimes it is quite noisy..this class started after school period.the time when primary school students went home..you see how this school is just beside the primary school...”]

From the finding above, the researcher concluded that time constraint, lack of motivation, inability to recall, emotional challenges, as well as external noises, were the challenges which impeded participants' motivation in memorizing. 


\section{Overcoming Challenges in the Memorization of the Qur'an}

When we manage to identify the barriers that hinder our motivation to memorize the Qur'an effectively, solutions should also be there to balance and overcome the obstacle. Based on the results of the interview, the researcher was able to find a number of techniques used by the participants to overcome their challenges and problems during the memorization of the Qur'an. These include empathy, parents' prayers and advice, continuous repetition, early morning practices, smart time management for memorization, having a partner to memorize, using punishment, introspection and help equipment. Table 6 below summarize the answers of all 6 participants.

\section{Table 6}

Students' techniques of overcoming challenges in memorization of the Qur' an

\begin{tabular}{cccccccccc}
\hline No & PP & E & CP & EP & ST & HP & P & I & OM \\
\hline P1 & $\sqrt{ }$ & $\sqrt{ }$ & & & & & & & \\
P2 & & $\sqrt{ }$ & $\sqrt{ }$ & $\sqrt{ }$ & $\sqrt{ }$ & $\sqrt{ }$ & & & \\
P3 & & & & & $\sqrt{ }$ & & $\sqrt{ }$ & $\sqrt{ }$ & \\
P4 & & & & & $\sqrt{ }$ & $\sqrt{ }$ & & & \\
P5 & $\sqrt{ }$ & & & & & & & & \\
P6 & $\sqrt{ }$ & & & & & & & & \\
\hline
\end{tabular}

Note. PP indicates parents' prayer, E indicates empathy, $\mathrm{CP}$ indicates continuous repetition, EP indicates early morning practices, ST indicates smart timetable, HP indicates having a partner, $\mathrm{P}$ indicates punishment, I indicates introspection,

$\mathrm{OM}$ indicates other materials

Table 6 above showed the techniques used by participants in overcoming challenges while memorizing the Qur'an through their own methods. Two participants believed that by putting themselves in others' shoes helped restore their motivation in memorizing while three participants stated that parents' prayers were the best methods to unblock their problem. Other than that, through continuous repetition, early morning practices, having a timetable for memorizing as well as a partner to memorize also help in overcoming the problems in memorization of the Qur'an. At the least, by doing punishment, introspection and getting other learning materials were also identified as techniques used by the participants in overcoming their problems while memorizing.

\section{Parents' Prayer and Advice}

In addition to this, participant 1 said that parents' prayer is very important, that she always asked her mother to pray for her.

"I am the oldest in my siblings, I would like to be an example to my siblings..."

"but I always ask my parents to pray for me..Mother's prayer is always answered, right?

This finding is similar to the answer of participant 6 who believed that advice from his parents somehow decrease the level of stress while memorizing the Qur'an. 
"usually I will ask advice from my parents or peer..."

"emmm...they told me to pray to Allah always as He is the one who control our mind...He can simply give and take what had been given to us...so I should always say alhamdulillah everytime I finish memorizing"

\section{Empathy}

Participant 1 stated that putting herself in others shoes as well as asking parents to pray for her helped in overcoming the challenges. When she felt like not having enough time to memorize the Qur'an and lost motivation to memorize, she:

"usually what I did was to read or find story of busy people that still manage to memorize Al-Qur'an though they might have load of works",

Participant 2 also mentioned the same:

"you know, by reading stories on how busy people can still manage to memorize the Qur'an, I think that had been much help for me to be motivated"

\section{Continuous Repetition}

Participant 2 pointed out his technique in order to overcome the barrier in the retrieval of the verses he had memorized by continuous repetition until he could master the Qur'anic verses.

"I just keep on reading and repeating the verses for maybe about 10 times. When I am confident that I had memorize it then only I move to other ayat."

He added by saying that:

"... when I read without understanding the meaning or 'tajwid', it has never been easy..but what I did was to keep on reading the verse without remembering it.."

\section{Early Morning Practices}

One of the participants responded that through practices early in the morning, he managed to memorize the Qur'an more effectively.

"I tried to consistently read and memorize early in the morning.." (Participant 2)

\section{Timetable for Memorization}

Some of the participants stated that they had their own timetable for memorization and revision of the verses that help them to be consistent in memorization.

"sometimes I draw a table on what to memorize so that I will not forget.." (Participant 2)

"saya cuba susun dan ikut jadual.. sekurang-kurangnya 2 jam sehari masa untuk hafalan..." ["I try to arrange and follow the timetable.. at least 2 hours a day to memorize.. ”] (Participant 3) 
"usually I will set 1 hour for memorization and another 3 hours to recall the verses.." (Participant 4)

In addition to that, participant 4 said that:

"as my memorization is getting wider, sometimes I just skip some easy verses and focus on verses which I am not confident enough to recall."

\section{Having Partner to Memorize}

Having a partner to memorize also help in overcoming the challenges in memorization.

"understanding the meaning or overview of the surah is very important..so having a partner in memorizing will be great" (Participant 2).

"sometimes I asked my memorization partner to come and memorize the Qur'an together...” (Participant 4).

\section{Punishment}

Another interesting technique used by one of the participants is that she used to punish herself with the additional page of Al-Qur'an if she did not manage to follow her timetable.

"saya akan denda diri saya dengan tambahan satu muka surat al-Qur'an..." ["I will punish myself with additional 1 page of Qur'an memorization..”](Participant 3)

\section{Introspection}

Participant 3 when asked about how she overcame her laziness pointed out her method by saying:

"selalunya saya akan ambil masa sekejap untuk muhasabah kenapa saya boleh malas..." ["usually I will take some time to analyze why am I being lazy..”]

\section{Other Learning Materials}

One participant pointed out the use of a headphone in the classroom as his own way to overcome the noises that disturb him while memorizing in the classroom.

"saya minta kebenaran kat cikgu untuk bawa headphone....pakai masa menghafal je...kurang sikit bunyi bising dari luar.. " ["I asked the teacher's permission to bring the headphone to school... used it while memorizing... the noise outside will be reduced.. "] (Participant 6)

From the above results, the researcher found that a number of techniques were used by the participants to overcome their challenges and problems during the memorization of the Qur'an. 
These include; empathy, through parents' prayer and advice, continuous repetition, early morning practices, smart timetable for memorization, having a partner to memorize, using punishment, introspection and help equipment.

\section{DISCUSSION}

The findings of this study proposed several factors of students' motivation and identified some challenges faced by students while memorizing the Qur'an in Sekolah Menengah Islam AlAmin Gombak (SMIAAG) and Sekolah Menengah Islam Al-Amin Bangi (SMIAAB) in the state of Selangor.

\section{Research Question 1}

Based on the study, the researcher found that three main factors influence the motivation of students - the family, the students themselves, and the role of teachers in motivating them. This is in line with the previous study by Norkhairolizah (2005) which found that parents played a major role in developing children's minds and academic goals, while at the same time establishing routines and monitoring their memorization of the Qur'an.

This finding also supports the further finding of Brophy (2008) where students' interest in learning can be maintained through a teacher's role in supporting their interest. Islam also identifies it as part of the worship that is inherent in human beings.

\section{Research Question 2}

The challenges which the researcher managed to identify included time constraint, lack of motivation, inability to recall, emotional challenges, as well as external noises. This result concurs with the finding of Waenalai (2009) on learning the memorization of al-Qur'an in Ma'had Nahdhotul 'Ulum Yala, South Thailand, where she found that the barriers which impeded students' interest in memorization of the Qur'an was lack of concentration.

Another study was done on visually impaired students' attitudes towards learning AlQur'an recitation and its relationship with the mastery of reading the Qur'an, which demonstrated a low opinion on their motivation. The reason seemed to be that the elements of awareness, motivation and encouragement are not there for them, as well as a lack of teachers' role in motivating them to read the Qur'an properly (Hajarul Bahti et al., 2014).

\section{Research Question 3}

Based on the result of the interview, several techniques used by the participants to overcome their challenges while memorizing include: empathy, parents' prayer and advice, continuous repetition, early morning practices, smart time management for memorization, having a partner 
to memorize with, using punishment, introspection and other learning materials. This is demonstrated in the study by Azmil Hashim et al. (2014), cited in Abu Najihat (2002), where they affirmed that students should be very focused in reading the Qur'an in order to memorize it. This was endorsed by JAKIM (2007) as cited by them, reminding students to recite the verses while performing their prayer.

Abdulsalam (2008) also mentioned that the Qur'an can be memorized line by line to enable students to comprehend the verses better and faster. This is also in accordance to Salasiah, et al. (2011), in their quote of the Prophet Muhammad's (pbuh) hadith: From Abu Hurairah r.a., Rasulullah (saw) said: A person's identity is in accordance with his friend's religion, so one must be scrupulous in determining who is suitable for being his friend (Narrated by Abu Daud, Kitab al-Adab).

\section{CONCLUSION}

To sum up, this study has shown how much motivation has influenced the students' memorization of the Qur'an. The finding suggested that parental guidance and advice were the most influential factors in motivating students to memorize the Qur'an. In addition, students themselves and teachers were also a source of motivation to memorize. The results also indicated a number of challenges faced by students while memorizing, including time constraints, lack of motivation, failure to recall, emotional challenges, as well as external noises. By knowing the factors and challenges involved in memorizing, the researcher outlined several techniques used by the participants to overcome their challenges and problems during the memorization of the Qur'an. These include empathy, parents' prayers and advice, continuous repetition, early morning practices, smart time allocation for memorization, having partners to memorize. In addition, using punishment, introspection, and auxiliary equipment, this study can be helpful as a resource for reducing the motivation gap in Qur'anic memorization. Hence, the researcher believes that this study will be valuable for other researchers to draw upon and pursue further in-depth the field of Qur'anic memorization in relation to motivation. 


\section{REFERENCES}

Al-Qur'an Al-Kareem

Al-Amin Tahfiz Center. (2012). Maklumat am program. Al-Qur'an \& Sunnah Department: Sekolah Menengah Islam Al-Amin.

Alizi, A., \& Mohammad Zaki, S. (2005). Psychology of motivation from an Islamic perspective. 3rd International Seminar on Learning and Motivation. Faculty of Cognitive Sciences \& Education, Universiti Utara Malaysia, Kedah, Malaysia.

Adam, M.L. (2016). Factors affecting students' motivation towards learning Islamic education subject in secondary school. International Islamic University Malaysia: Unpublished Master thesis.

Aragon, S. R. (2002). An investigation of factors influencing classroom motivation for postsecondary American Indian/ Alaska native students. Journal of American Indian Education, 41(1), 1-18.

Ariffin, S., Amir, S., Abdullah, M., Suliaman, I., Ahmad, K., Deraman, F., Ahmad Shah, F., Mohd Yusoff, Mohd Yakub @ Zulkifli, Abd Razzak, M.M., Mohd Noor, M.M., Touhami Meftah, J., K. Kassar, A., \& Mohd Nor, M.R. (2013). Effective techniques of memorizing the qur'an: a study at Madrasah Tahfiz Al-Qur'an, Terengganu, Malaysia. Middle-East Journal of Scientific Research, 13 (1). pp. 45-48. ISSN 1990-9233

Ariffin, S., Abdullah, M., \& Ahmad, K. (2013). Module of al-Qur'an memorization according to capability and period. International Proceedings of Economics Development and Research umexpert.um.edu.my/file/publication.

Azmil Hashim, Ab Halim Tamuri \& Mohd Aderi Che Noh. (2014). The relationships between etiquettes of tahfiz (memorization al-Quran) and tahfiz achievement. Australian Journal of Basic and Applied Sciences, 8(23), 212-218.

Baxter, P., \& Jack, S. (2008). Qualitative case study methodology: Study design and implementation for novice researchers. The Qualitative Report, 13(4), 544-559.

Boyle, H. N. (2006). Memorization and learning in Islamic schools. Comparative Education Review, 50(3), 478.

Brophy, J. (1998). Motivating students to learn. New York: Mc Graw Hill.

Chang, H.H. (2005). The relationship between extrinsic/intrinsic motivation and language learning strategies among college students of English in Taiwan. Master thesis.

Entwistle, N. \& Entwistle, D. (2003). Preparing for examinations: the interplay of memorizing and understanding, and the development of knowledge objects. Higher Education Research \& Development.

Hajarul Bahti, Z., Ab Halim, T, Norshidah, M.S. \& Mohd Huzairi, A. (2014). Students' attitudes towards learning al-Qur'an recitation and its relationship with the mastery of reading the al-Qur'an among visual impaired students in Malaysia. International Conference on Economics, Education and Humanities, Dec 10-11, 97-100. 
JAKIM. (2007). Kaedah hafazan al-Qur'an. Selangor. Medan Hikmah Sdn. Bhd.

Ministry of Education. (2016). Surat Pekeliling Ikhtisas Kementerian Pendidikan Malaysia. Bil. 1 2016: Pelaksanaaan Tahfiz Model Ulul Albab di Sekolah Menengah KPM.

Muhammad Hafiz Khamis. (2011). A study of students' learning styles in memorizing AlQur'an: CCAC Tahfiz Programme. Unpublished Master thesis.

Muhammad Ikhwanuddin. (2013). The relationships between memorization techniques and understanding of the Qur'an. Unpublished Master thesis.

Nik Abdullah, N. M. S. A. (2014). Strategi dalam menghafal Al-Qur'an di Institusi Tahfiz Darul Qur'an di Malaysia. Unpublished Doctoral Dissertation, International Islamic University Malaysia (IIUM), Kuala Lumpur.

Nik Abdullah, N. M. S. A. (2019). Challenges and Difficulties in Memorizing the Qur'an in the Tahfiz Classes Among Secondary Learners. AL-BURHĀN International Islamic University Malaysia (IIUM), Kuala Lumpur, 3(2), 1-14. e-ISSN 2600-83863

Norkhairolizah, H. (2005). Parental Role in Promoting Children's Qur'anic Memorization. Unpublished Master thesis.

Nor Musliza Mustafa, \& Mokmin Basri. (2014). Perbandingan Kaedah Hafazan Al-Qur'an Tradisional Dan Moden: Satu Kajian Awal. Proceeding of the Social Sciences Research ICSSR, 9-10 June: Kota Kinabalu, Sabah.

Ola, A. K., \& Kole, J. (1991). An Islamic perspective on the expectancy-valence theory. The American Journal of Islamic Science, 8(3), 453-460.

Patnaik, G. (2014). Lived Experiences of Iraqi Refugee Students in Community Colleges. Unpublished Doctoral Dissertation.

Pintrich, G. (1996). Motives, goals and adaptive patterns of performance in asian-American and Anglo-American students. Learning and Individual Differences, 15, 141-158.

PITAS. (2019). Persatuan Institut Tahfiz Selangor (PITAS). https://pitas.com.my/page/ pagedetail.php?schid=181\&schname=map $\% 20$ madrasah

Salasiah Hanin Hamjah, Zainab Ismail, Rosmawati Mohamad Rasit \& Ermy Azziaty Rozali. (2011). Methods of increasing learning motivation among students. Procedia Social and Behavioral Sciences, 18, 138-147.

Saudullah Ali. (2003). Students' opinion on teaching strategies to motivate to learn Islamic studies in secondary schools of Maldives. Unpublished Master thesis.

Seifert, K. \& Sutton, R. (2018). Motivation Theories on Learning. R. E. West, Foundations of Learning and Instructional Design Technology: The Past, Present, and Future of Learning and Instructional Design Technology. EdTech Books. https://edtechbooks.org /lidtfoundations/motivation_theories_on_learning 
Shahrudin, K. A., Nusran, Z. M., \& Rahmat, S, J,. (2015). Penguasaan hukum ra' ketika membaca al-Qur'an dalam kalangan murid tahun enam. Institut Pendidikan Guru: Kampus Pendidikan Islam. http://www.ipislam.edu.my/index.php/research/read /15/Penguasaan-Hukum-Ra-Ketika-Membaca-Al-Qur'an-dalam-Kalangan-MuridTahun-Enam.

Sulaiman Ibn al-Asy'ath bin Ishaq al-Azdiyy al-Sijistani (2000). Kitab al-sunan: Sunan Abi Daud. Beirut, Dar Ihya' al-Turath al-'Arabi.

Tuckman B.W. \& Monetti, D. M. (2010). Educational psychology. Wadsworth Cengage Learning.

Waenalai, K. (2009). Pembelajaran menghafal al-Qur'an di Ma'had Nahdhotul 'Ulum Yala Thailand Selatan. Unpublished Master thesis.

Wirth, K. R., \& Perkins, D. (2007). Learning to learn. cgiss.boisestate.edu/ billc/ Teaching/Items/learningtolearn

Yusof, R.J.R, Zainudin, R., Baba, M.S., Yusoff, Z.M., Jomhari N. 2012. Visualizing Qur'anic words with parallel plot. Malaysian Journal of Computer Science (ISSN 0127- 9084), 25(2), 2012, pp 90-106.

Zahera, R. (2012). Improving students learning motivation through mim-mem method on tahfizul Qur'an of short surah material at the third year of state elementary school 006 limau manis kecamatan Kampar Kabupaten Kampar. Unpublished Master thesis. 